\title{
Yield of Sweetpotato Cuttings Is Not Influenced by Shoot Apex or Polarity
}

Melvin R. Hall ${ }^{1}$

Department of Horticulture, University of Georgia Coastal Plain Experiment Station, Tifton, GA 31793

Additional index words. Ipomoea batatas, transplant

Cuttings taken from the vines of established sweetpotatoes maybe used to establish field plantings (Edmond, 1971). These vine cuttings are cut from stock plants five or six nodes below the shoot apex in $20-$ to $30-\mathrm{cm}$ sections and then cut serially along the length of the same vine.

The acropetal end should be oriented aboveground for transplanting. Since sweetpotato vines grow prostrate on the soil surface, leaves may not always be oriented in the acropetal direction toward the shoot apex. Therefore, leaf orientation is not an accurate indicator of polarity for sweetpotato vine cuttings, but the shoot apex and axillary buds assist in identifying shoot polarity. However, absence of the shoot apex hampers rapid determination of polarity, and cuttings must be closely examined for orientation of the axillarv buds to ensure that they are planted in an upright position. Such difficulty often results in some cuttings being transplanted with a reversed polarity (inverted) in commercial sweetpotato fields. In a previous study, removing the shoot apex increased vine branching but did not influence U.S. \#1 or total marketable yield (Hall, 1987). The combined influence of the shoot apex and polarity of cuttings on sweetpotato root yield has not been described. The objective of this work was to determine the influence of the shoot apex and polarity of transplanted vine cuttings on sweetpotato root yield.

Received for publication 17 Mar. 1993. Accepted for publication 13 Aug. 1993. Mention of a trademark, proprietary product,orvendordoesnot imply endorsement by the Georgia Agricultural Experiment Stations, nor criticism of similar products not mentioned. This research was supported by state and Hatch Act funds allocated to the Georgia Agricultural Experiment Stations. The cost of publishing this paper was defrayed in part by the payment of page charges. Underpostalregulations, thispaper therefore must be hereby marked advertisement solely to indicate this fact.

${ }^{1}$ Associate Professor.
Vine cuttings $30 \mathrm{~cm}$ long and retaining their shoot apex were cut from 'Red Jewel' stock plants in each of 2 years. To avoid possible yield performance differences in cuttings due to position on the stock plant vine, cuttings without the primary shoot apex were prepared by removing the apex just below the node of the first fully expanded leaf and then trimming to $30 \mathrm{~cm}$ at the basipetal end. Plots were established on a Tifton loamy sand (fineloamy, siliceous, thermic Plinthic Kandiudults) using standard cultural practices (Granberry and McLaurin, 1990). Cuttings were transplanted manually $30 \mathrm{~cm}$ apart in $7.6 \times 1.3-\mathrm{m}$ plots on 12 June 1987 and 3 Aug. 1988. Shoot apex removal and polarity were evaluated using a randomized complete block arranged in a $2 \times 2$ factorial with five replications of 25 cuttings. Plots were irrigated by overhead sprinklers with $25 \mathrm{~mm}$ of water immediately after planting and then as needed to maintain adequate plant growth. Plant survival was evaluated 21 days after transplanting. Plots were harvested 125 and 116 days from transplanting in 1987 and 1988, respectively. Marketable roots were sorted into grades: U.S. \#1 (5 to $9 \mathrm{~cm}$ in diameter, 7.5 to $23 \mathrm{~cm}$ long), canner ( 2.5 to $5 \mathrm{~cm}$ in diameter, 5 to $18 \mathrm{~cm}$ long), and jumbo (exceeds length and diameter requirements of U.S. \#1 grade). Although there were no significant interactions of year with any of the treatments, results were not combined over years because analyses of variance indicated significant differences between years (Gomez and Gomez, 1976).

All transplants survived (data not shown). Neither presence of the shoot apex nonpolarity influenced yields of individual root grades or total of marketable grades in either year. U.S. \#1 yields were $\approx 20 \mathrm{t} \cdot \mathrm{ha}^{-1}$ in $1987 \mathrm{and} \approx 11 \mathrm{t} \cdot \mathrm{ha}^{-1}$ in 1988; the respective total marketable yields were $\approx 26 \mathrm{t} \cdot \mathrm{ha}^{-1}$ and $18 \mathrm{t} \cdot \mathrm{ha}^{-1}$. These findings were similar to earlier results that showed a lack of yield influence with removal of the shoot apex from cuttings transplanted with an upright polarity (Hall, 1987) and demonstrated a similar response from cuttings transplanted with an inverted polarity. Also, these findings support growers' claims that polarity of transplanted vine cuttings does not adversely affect sweetpotato root yields. During establishment of transplanted sweetpotato vine cuttings, fibrous roots develop from underground nodes. Later, enlarged storage roots also develop. Regardless of whether the shoot apex is present, one or more axillary buds usually elongate from the aboveground nodes of transplanted sweetpotato vine cuttings. In these plantings, visual observations did not indicate differences in vine growth between upright and inverted cuttings during the first 3 weeks after transplanting. At harvest, all treatment combinations displayed similar fibrous root development from underground nodes of the original cutting and characteristic storage root development.

There are two possible explanations for these observations and for the lack of influence of experimental treatments on yield. Sweetpotato vine cuttings maybe insensitive to polarity, but evidence with other species (Goldsmith, 1969) does not generally support this possibility. Alternatively, an axillary bud at or near soil level may have elongated, rooted, and subsequently developed storage roots. This possibility resembles the shoot and fibrous root development pattern of redcurrant (Ribes rubrum L.) cuttings planted in an inverted position (Hartmann and Kester, 1983). Buds on sweetpotato vine cuttings transplanted with either an inverted or an upright polarity could have displayed a similar developmental pattern. However, the present data do not explain the lack of influence of experimental treatments on yields, and further study of vine and storage root development from transplanted vine cuttings is suggested before the polarity response can be generalized.

\section{Literature Cited}

Edmond, J.B. 1971. Field production practices and operations, p. 123-147. In: J.B. Edmond and G.R. Ammermarr (eds.). Sweet potatoes: Production, processing, and marketing. AVI, Westport,Conn.

Goldsmith,M.H.M.1969.Transportofplant growth regulators, p. 127-162. In: M.B. Wilkins (cd.). The physiology of plant growth and development. McGraw-Hill, New York.

Gomez, K.A. and A.A. Gomez. 1976. Statistical procedures for agricultural research. 2nd ed. Wiley, New York.

Granberry, D.M. and W.J. McLaurin. 1990. Sweet potato. Georgia Coop. Ext. Serv. Circ. 677.

Hall, M.R. 1987. Shoot apex and nodes exposed above-ground influenced growth of sweet potato vine cuttings. HortScience 22:230-232.

Hartmann,H.T. and D.E. Kester. 1983. Anatomical and physiological basis of propagation by cuttings.In Plant propagation,principles and practices. 4th ed. Prentice Hall, Englewood Cliffs, N.J. 